Sarı, B. ve Altun, D. (2018). Okul öncesi dönem çocuklarının hikâye anlama ile zihin kuramı becerileri arasındaki ilişkinin incelenmesi. Ana Dili Eğitimi Dergisi, 6(4), 945-960.

$\begin{gathered}\text { Ana Dili Eğitimi Dergisi } \\ \text { Journal of Mother Tongue Education } \\ \text { www.anadiliegitimi.com }\end{gathered}$
Geliş/Received: 06.07 .2018 Kabul/Accepted:11.09.2018

\title{
Okul Öncesi Dönem Çocuklarının Hikâye Anlama ile Zihin Kuramı Becerileri Arasındaki İlişkinin İncelenmesi
}

\author{
Burcu SARI* \\ Dilek ALTUN ${ }^{* *}$ \\ Öz
}

Bu araştırmanın amacı okul öncesi dönem çocuklarının hikâye anlama ile Zihin Kuramı becerileri arasındaki ilişkiyi araştırmaktır. Araştırma ilişkisel tarama modelinde yürütülmüştür. Araştırmanın çalışma grubunu, 2017-2018 eğitim öğretim yılı güz döneminde Kırşehir il merkezinde bulunan Milli Eğitim Bakanlığına bağlı dört bağımsız anaokulunda eğitimine devam eden 133 (67 kız, 66 erkek) çocuk oluşturmaktadır. Araştırmanın verileri Zihin Kuramı Ölçeği ve Hikâye Anlama Soruları kullanılarak toplanmıştır. Çalışma kapsamında Frederick ve Ağustos Böceği ile Karınca hikâyeleri çocuklara okunmuştur. Araştırma bulguları, hikâye anlama toplam puanları ile Zihin Kuramı Ölçeği toplam puanları arasında pozitif yönlü orta düzeyde bir ilişki $(r=.46)$ olduğunu göstermiştir. Zihin Kuramı Ölçeği'nin alt boyutları ile Hikâye anlama toplam puanları arasındaki ilişki incelendiğinde, içerik Yanlış Inanış alt boyutu en yüksek korelasyon katsayısına ( $r=.43)$ sahipken, Farklı istek alt boyutu en düşük korelasyon katsayısına ( $r=.16)$ sahip olduğu bulunmuştur. Ayrıca, çocukların hikâye anlama ve Zihin Kuramı puanları arasında cinsiyet değişkeni açısından kızların lehine anlamlı bir fark bulunmuştur. Çalışma bulguları ilgili alanyazın ışığında tartışımıştır.

Anahtar Kelimeler: Okul Öncesi eğitim, Zihin Kuramı, Hikâye Anlama, Hikâye kitapları

\section{An Examination of the Relationship between Preschoolers' Story Comprehension and Theory of Mind Skills}

\begin{abstract}
This study aims to reveal the relationship between preschool children's story comprehension and Theory of Mind skills. The study was conducted, using the correlational survey model. The study group consists of 133 (67 girls and 66 boys) children, selected through the convenience sampling method, studying at four public kindergarten that are located in the central district of Kirsehir province of Turkey in the Fall semester of the 2017-2018 academic year. The study data were collected, using the Theory of Mind Scale and Story Comprehension Questions. Two illustrated storybooks titled Frederick and Ağustos Böceği ile Karınca [The Ant and the Grasshopper] were read to the children during the study. According to the findings, a moderate positive correlation was found between story comprehension and Theory of Mind $(r=46)$. The highest correlation between the subtasks of the Theory of Mind and story comprehension was in the Content False Belief task $(r=43)$, while the lowest correlation was in the Diverse Desires task $(r=16)$. Additionally, a significant difference was found in favor of the girls between story comprehension and Theory of Mind in terms of gender. The study findings are discussed in the light of the relevant literature.
\end{abstract}

Keywords: Preschool education, Theory of Mind, Story Comprehension, Storybooks.

\footnotetext{
${ }^{*}$ Arş. Gör. Dr., Çanakkale Onsekiz Mart Üniversitesi, Sosyal Bilimler Meslek Yüksekokulu, Çocuk Gelişimi Programı, burcusari87@gmail.com, ORCID ID: 0000-0002-2872-8613

${ }^{* *}$ Dr. Öğr. Üyesi, Kırşehir Ahi Evran Üniversitesi, Eğitim Fakültesi, Okul Öncesi Eğitimi ABD, daltun@ahievran.edu.tr, ORCID ID: 0000-0002-9973-0585
} 


\section{Giriş}

Dil genel anlamda, insanların iç dünyalarını, yaşantılarını, duygu ve düşüncelerini sözlü veya yazılı olarak aktarmaya yardımcı bir araç olarak tanımlanmaktadır (Karaağaç, 2010; Yılmaz, 2009). Dil gelişimi anne karnında bebeğin, anadiline özgü sesleri tanıyarak gelişmeye başladığı bilinmektedir (Minai, Gustafson, Fiorentino, Jongman ve Sereno, 2017). Doğumdan sonraki ilk altı yıl gelişimin en hızlı olduğu dönemdir. Bu dönemde birçok gelişim alanının olduğu gibi dil gelişiminin de temeli atılmaktadır (Başal, 2012; Sakai, 2005). Boylamsal çalışma sonuçları erken çocukluk dönemi dil becerilerinin ileriki dönem dil ve okuma becerileri ile ilişkili olduğunu göstermektedir (Duff, Reen, Plunkett ve Nation, 2015; Duncan vd., 2007; Su vd., 2017).

Çocukların okul öncesi dönemde dil gelişimlerini değerlendirirken göz önünde bulundurulan becerilerinden bir tanesi de hikâye anlama becerisidir. Hikâye anlama becerisi, çocuğun erken dönemde kazanmaya başladığı temel dil becerileriyle ilkokul döneminde kazanacağı okuma becerileri arasında bir köprü görevi görmektedir (Demir-Lira, 2016). Suggate, Schaughency, McAnally ve Reese (2018) tarafında yürütülen 10 yıllık boylamsal çalışma sonuçlarına göre, çocukların okul öncesi dönemde dinlediği hikâyeleri anlama beceri ile ileriki dönem okuduğunu anlama becerileri arasında anlamlı bir ilişki bulunmaktadır. Ayrıca bu çalışma sonuçları hikâye anlama becerisinin de dil becerileri gibi gelişimsel bir süreç içerisinde kazanıldığını göstermektedir.

\section{Hikâye Anlama}

Hikâye kitapları, olay örgüsü, hikâye kahramanları ve bu kahramanların arasındaki etkileşimden oluşmaktadır. Ayrıca, hikâye kitapları çocuklara hikâyede yer alan karakterlerin davranışlarını ve karakterlerin bu davranışlarını şekillendiren duygularını ve düşüncelerini aktarmayı da sağlamaktadır (Dyer, Shatz ve Wellman, 2000). Hikâye anlama becerisi birçok alt beceriyi kapsamaktadır. Bu beceriler, hikâyedeki temel fikri bulabilme, olaylar arasındaki neden sonuç ilişkisini belirleyebilme, olay örgüsünü doğru şekilde sıralayabilme, metinde geçen bağlantıları bulabilme ve bu bağlantıları kendi yorumuyla ilişkilendirebilme ve hikâyede geçen olayları özetleyebilme şeklinde sıralanabilir (Morrow, 1985; Paris ve Paris, 2003; Sipe, 2008; Stein, 1978).

Çocukların hikâyedeki olay örgüsü üzerinden anlam çıkarma ve değerlendirme yapabilme becerileri, onların hem karakterin hem yazarın hem de okuyucunun bakış açısından düşünebilme ve konuşabilme yetenekleriyle ilişkilidir (Pelletier ve Astington, 2004). Fernández'e (2013) göre, çocukların hikâye anlama becerilerinin gelişiminin bir göstergesi de çocukların hikâyedeki olay örgüsüne ve temaya kendilerini dâhil edebilme yeteneğidir. Sulzby (1985) okuma deneyimi açısından daha az deneyime sahip çocukların hikâye kitaplarındaki görsellere odaklanmakta olduğunu ve sadece resimlerde gördüğü kadarına yorum yapabildiğini belirtmiştir. Çocukların okuma deneyimi 
arttıkça hikâyenin içyapısına aşina olmaya başlamaktadırlar. Örneğin; çocuklar çok sevdikleri bir hikâye kitabının genellikle defalarca okunmasını istemektedirler. Kitabı tekrar tekrar okudukça sözel metni içselleştirmektedirler. Bu sayede çocuklar hikâyenin içyapısını anlamaya ve yorumlamaya başlamaktadırlar.

Çocukların hikâyede yer alan karakterlerin davranışlarının altında yatan niyetlerini ve düşüncelerini gelişimsel bir süreç içinde anlamaya başladıkları düşünülmektedir. Astington (1990) çocukların dört yaşına gelene kadar hikâye anlatımlarının değerlendirilemeyeceğini savunmaktadır. Bunun nedeni olarak da, çocukların hikâyedeki zihinsel durumları anlamak için gerekli olan bilişsel becerilerinin henüz yeterli düzeyde gelişmediğini ifade etmektedir. Astington’a (1990) göre, çocuklar hikâyelerin ilişkili (referential) ve değerlendirici (evaluative) içeriğini anlamaya yönelik tam bir kavrayışa sahip değillerdir (Akt. Pelletier ve Astingon, 2004). Okul öncesi dönem çocukları hikâye anlatımında genellikle hikâyenin olay örgüsünü sırayla anlatmaya odaklanmaktadır. Çocukların olay örgüsünü hikâyedeki karakterlerin duygu ve düşünceleriyle ilişkilendirebilmesi onların zihinsel durumları anlama ve ifade edebilme becerilerine sahip oldukları zaman mümkün olmaktadır (Pelletier ve Astingon, 2004). Gamannossi ve Pinto (2014) çocukların hikâye anlatımında zihinsel durumları ifade eden dil kullanımı ile çocukların zihinsel durumları anlama becerileri arasındaki ilişkiyi incelemişlerdir. Araştırma sonuçları, hikâye anlama becerisi ile hikâye anlatımında zihinsel durumları ifade eden dil kullanımı arasında güçlü bir ilişkinin $(r=.79)$ olduğunu ortaya koymuştur. Yapılan araştırmalar Zihin Kuramı becerilerinin çocukların hikâye anlama düzeyine genel kelime bilgisinden daha fazla katkı sağladığını da göstermektedir (Pelletier ve Beaty, 2015).

Alanyazında yer alan araştırmalar ışığında; dil gelişiminde sadece kelime bilgisi, hikâye anlama becerisi gibi dil becerilerinin değil aynı zamanda çocuğun zihinsel durumları anlayabilme düzeyini gösteren bilişsel becerilerin de önemli olduğu görülmektedir. Günümüzde çocukların zihinsel durumları anlayabilme becerisini araştıran birçok çalışmada Zihin Kuramı́nın ele alındığı görülmektedir (Charman, Baron-Cohen, Swettenham, Baird, Cox ve Drew, 2000; Grazzani, Ornaghi, Conte, Pepe ve Caprin, 2018; Milligan, Astington ve Dack, 2007). 1980'li yıllardan önce çocukların zihinsel gelişimlerini inceleyen araştırmalar meta-bilişsel kuramı ya da Piaget'in bilişsel gelişim kuramını temel alarak yürütülmekteydi. 1980'li yılların ortalarından itibaren bilişsel gelişimi araştıran çalışmalarda Zihin Kuramı́nın da kullanıldığı görülmektedir (Flavell, 2000).

\section{Zihin Kuramı}

Zihin Kuramı (Theory of Mind) becerileri, en temel tanımıyla başkalarının duygularını, niyetlerini ve arzularını anlayabilme becerisi olarak tanımlanmaktadır (Milligan vd., 2007; Wellman ve Liu, 2004). Zihin Kuramı, dil gelişimi gibi gelişimsel bir süreci takip etmektedir. Bebekler doğdukları 
andan itibaren çevresinde yer alan insanlarla etkileşim halindedirler. Çocuklar iki yaşına geldiğinde istek ve duyguları hakkında konuşmaya başlamaktadırlar. Çocuklar üç-dört yaşına geldikten sonra düşüncelerini de dile getirmeye başlarlar. Bu yaşta çocuklar karşısındaki kişinin sadece inanışlarına göre hareket etmediğini aynı zamanda hatalı veya yanlış inanışlara göre de hareket edebileceklerini anlamaktadırlar. Ayrıca, görünüşle gerçeklik arasındaki farkı ayırt edebilmektedirler (Wellman, 2014). Zihin Kuramı, farklı alt becerilerin kazanımı ile değerlendirilmektedir. Bu beceriler (a) Farkı İstekler: İnsanların aynı şeye karşı farklı arzularının olabileceğini anlayabilme, (b) Farklı Inanışlar: İnsanların aynı durum karşısında farklı inanışları olabileceğini anlayabilme, (c) Bilgi Erişsimi: Bazı durumlar doğru olabilir fakat başkasının bu durumla ilgili bilgi eksikliği olabileceğini anlama, (c) Yanlış Inanış: Bazı durumlar doğru olabilir fakat başkasının bu durumla ilgili farklı inanışa sahip olabileceğini anlama, (d) Saklı Duygu: Bazı insanlar bir duyguyu hissedebilir fakat insanların hissettiğinden farklı bir duyguyu da yansıtabileceğini anlama şeklinde kısaca açıklanabilir. Bu beceriler sırasıyla basitten zora doğru bir gelişim göstermektedir. Farklı İstekleri anlama becerisi en kolay düzeydeki beceri iken Saklı Duyguyu anlama Zihin Kuramı becerilerinin en zor seviyesidir (Wellman, 2014). Keçeli-Kaysılı ve Acarlar (2011) Türk çocuklarının Zihin Kuramı becerilerini kazanımlarını gelişimsel olarak incelemişlerdir. Türk çocuklarının Zihin Kuramı Ölçeği'nin alt boyutlarından İçerik Yanlış inanış değerlendirme becerisini ortalama 4 yaş 6 ay civarında kazandıklarını tespit etmişlerdir. Araştırma sonuçları, Türk çocuklarının da alanyazında tespit edilen Zihin Kuramı gelişim sırasına benzer bir sıra ile bu becerileri kazandıklarını göstermektedir.

Alanyazında yer alan araştırmalar Zihin Kuramı́nın dil gelişimi ile ilişkili olduğunu göstermektedir (Astington ve Jenkins, 1999; Atkinson, Slade, Powell ve Levy, 2017; Charman ve Shmueli-Goetz, 1998; Milligan vd., 2007; Wellman, 2014). Ayrıca, bazı araştırmalarda da çocukların Zihin Kuramı ve hikâye anlama becerileri arasında ilişki olduğunu ortaya koymaktadır (Adrian, Clemente, Villanueva ve Rieffe, 2005; Guajardo ve Watson, 2002; Pelletier ve Beaty, 2015; Peskin ve Astington, 2004; Ruffman, Slade ve Crowe, 2002). Pelletier ve Beaty (2015) okul öncesi dönem çocuklarının fablları anlama düzeyleriyle Zihin Kuramı becerileri arasında anlamlı ilişki bulmuşlardır. Fernández (2013) tarafından yapılan başka bir araştırma ise, gelişmiş Zihin Kuramı becerilerine sahip çocukların hikâyedeki karakterin zihinsel durumlarını anlamlandırma becerisinde daha üst düzey başarı gösterdiklerini belirtmektedir. Bu çalışma sonuçları, hikâyelerde sadece olay örgüsünün hatırlanmasının önemli olmadığını aynı zamanda hikâyede yer alan karakterin olaylara bakış açısı ve olaylardan çıkardığı anlamın da önemli olduğunu göstermektedir.

Yapılan araştırmalar Zihin Kuramı ile hikâye anlama becerileri arasında ilişki olduğu göstermektedir. Bununla birlikte, hikâye anlama becerisini Zihin Kuramı alt becerilerine göre inceleyen ilişkisel araştırmalara ihtiyaç duyulduğu da görülmektedir. Ülkemizde bu alanda yapılan 
Okul Öncesi Dönem Çocuklarının Hikâye Anlama ile Zihin Kuramı Becerileri Arasındaki iliş̧kinin İncelenmesi

çalışmalar incelendiğinde, okul öncesi dönem çocuklarının hikâye anlama ve Zihin Kuramı becerilerini ele alan basılı bir araştırmaya araştırmacılar tarafından ulaşılamamıştır. Bu araştırmanın amacı okul öncesi dönem 5-6 yaş çocuklarının hikâye anlama ile Zihin Kuramı becerileri arasındaki ilişkiyi incelemektir. Bu araştırma kapsamında aşağıda yer alan sorulara cevap aranmıştır:

1) Okul öncesi dönem çocuklarının Zihin Kuramı Ölçeği puanları cinsiyete göre farklılaşmakta mıdır?

2) Okul öncesi dönem çocuklarının hikâye anlama puanları cinsiyete göre farklılaşmakta midır?

3) Okul öncesi dönem çocuklarının Zihin Kuramı ile hikâye anlama puanları arasındaki ilişki var midır?

\section{Yöntem}

\section{Araştırmanın Modeli}

Okul öncesi dönem çocuklarının Zihin Kuramı ve hikâye anlama becerileri arasındaki ilişkiyi inceleyen bu çalışma nicel araştırma yöntemlerinden ilişkisel tarama modelinde yürütülmüştür. İlişkisel araştırmalar, iki ya da daha fazla değişken arasında var olan ilişkiyi ve bu ilişkinin derecesini herhangi bir değişkene müdahalede bulunmadan incelemeyi amaçlamaktadır (Fraenkel, Wallen ve Hyun, 2012).

\section{Araştırma grubu}

Araştırmanın çalışma grubunu, 2017-2018 eğitim öğretim yılı güz döneminde Kırşehir il merkezinde bulunan Milli Eğitim Bakanlığına bağıı dört bağımsız anaokulunda eğitimine devam eden 133 çocuk (67 kız, 66 erkek) oluşturmaktadır. Çalışma grubu, tesadüfi olmayan örnekleme yöntemlerinden, uygun örnekleme yöntemi ile seçilmiştir (Fraenkel vd., 2012). Çalışma için gerekli etik ve uygulama izinleri alındıktan sonra, ebeveynlere çalışmaya ilişkin bilgilendirme ve veli onay formu gönderilmiştir. Ebeveynlere gönderilen 200 veli onay formundan 138 tanesi çalışmaya çocuklarının katılmasına izin vermiştir. Çocuklardan 5 tanesi gelişimsel ve öğrenme problemleri nedeniyle çalışma dışında bırakılmıştır. Araştırma grubunu oluşturan çocukların \%50.40’u ( $n=67)$ kız; \%49.60'ı ( $n=66$ ) ise erkektir. Çocukların yaş ortalamaları 61.80 aydır (dağılım: 58-69 ay).

\section{Veri Toplama Araçları}

Araştırmanın verileri Zihin Kuramı Ölçeği ve Hikâye Anlama Soruları kullanılarak toplanmıştır. Çalışma kapsamında "Frederick" ve "Ağustos Böceği ile Karınca" isimli iki hikâye çocuklara okunmuştur. 
Zihin Kuramı Ölçeği: Wellman ve Liu (2004) tarafından çocukların bir başkasının zihinsel durumlarını (duygu, düşünce, istek, niyet vb.) anlama düzeylerini ölçmek amacıyla geliştirilmiştir. Zihin Kuramı Ölçeği, Gözün Kahraman (2012) tarafından Türkçeye uyarlanmış ve güvenirlik katsayısı KR-20 değeri .50 ve test tekrar test güvenirliğine ilişkin Korelasyon katsayısı .78 olarak bulunmuştur. Türkçeye uyarlanan Zihin Kuramları Ölçeği beş görevden oluşmaktadır. Bu görevler sırasıyla şunlardır: "Farklı Istek", "Farkı Inanış", "Bilgi Erişimi", "içerik Yanlış Inanış", ve "Saklı Duygu". Ölçekte yer alan bu beş göreve ilişkin senaryolar, görseller kullanılarak PowerPoint sunusu şeklinde hazırlanmıştır. Dizüstü bilgisayar kullanılarak ölçek çocuklara bireysel olarak uygulanmıştır. Ölçeğin puanlaması her bir görev için doğru cevaba " 1 ", yanlış cevaba "0" verilerek yapılmaktadır. Çocukların ölçekten alabilecekleri puanlar 0 ile 5 puan arasında değişmektedir.

Hikâye Anlama Soruları: Okul öncesi dönem çocuklarının hikâye anlama düzeylerini belirlemek amacıyla Paris ve Paris (2003) tarafından geliştirilen sorular kullanılmıştır. Hikâyeler için oluşturulan sorular, "karakter", "sahne", "başlangıç olayı", "problem" ve "sonuç-çözüm" gibi beş başlık altında çocukların hikâye ögelerine ilişkin anlama düzeylerini ölçmeyi amaçlamaktadır. Çocukların sorulara verdikleri cevaplar yanlışsa "0", kısmi doğruysa "1" ve doğruysa "2" olarak puanlanmaktadır. Örneğin: Ağustos Böceği ile Karınca hikâyesi için çocuk hikâyede yer alan kahramanlar ile ilgili cevap vermezse ya da yanlış cevap verirse " 0 ", sadece ağustos böceği ya da karıncadan birini söylerse "1" ve her iki kahramanın da adını söylerse "2" puan almaktadır. Çocukların hikâye anlama sorularından alabilecekleri puanlar 0 ile 10 puan arasında değişmektedir.

Hikâye Kitapları:

Frederick: Leo Lionni tarafından yazılmış ve resimlenmiştir. Frederick 1968 yılında Caldecott Onur ödülünü kazanmıştır. Kitap, Kemal Atakay tarafından Türkçeye çevrilmiştir. Hikâye, kardeşleri kışa hazırlık yapmak için harıl harıl yiyecek toplarken, oturup etrafı izleyen tarla faresi Frederick'i anlatmaktadır. Ağustos Böceği ve Karınca hikâyesinin tersine, bu hikâyede kış gelince kardeşleri Frederick ile yiyeceklerini paylaşmaktalar ve Frederick'in sanatsal becerilerini takdir etmektedirler.

Ağustos Böceği ile Karınca: Lesley Sims tarafından yeniden kaleme alınan hikâye ilke Afacan tarafından Türkçeye çevrilmiştir. Bu hikâyenin farklı uyarlamaları incelenmiş ve Ağustos Böceği'nin donarak ölme sahnesine yer veren kitaplar elenmiştir. Bu hikâyenin sonu Karınca, Ağustos Böceği'ne yardım etmemiş şeklinde değiştirilerek çocuklara okunmuştur.

Araştırmada bu iki kitabın kullanılma sebeplerinden biri, iki kitabın benzer bir temayı farklı bakış açılarıyla çocuklara aktarmasıdır. Ayrıca iki kitapta da var olan tema havyanlar aracılığıyla çocuklara sunulmaktadır. Bazı bağlamlarda, insan olmayan karakterlerin kullanımı, okuyucunun/ dinleyenin duygularını çağrıştırmak ve geniş kitlelere hitap etmek için kullanıldığı bilinmektedir 
Okul Öncesi Dönem Çocuklarının Hikâye Anlama ile Zihin Kuramı Becerileri Arasındaki ilişskinin İncelenmesi

(Pelletier ve Beatty, 2015). Bu sebeple benzer olaya farklı bakış açıları sunduğu ve çocukların duygularını çağrıştırabileceği düşünülen bu iki kitap araştırmada kullanıımıştır.

\section{Verilerin Toplanması}

Araştırmanın verileri, okul öncesi dönem çocuklarının dikkat süreleri göz önünde bulundurularak üç oturumda toplanmıştır. İlk oturumda çocuklara birebir Zihin Kuramı Ölçeği uygulamıştır. Çocukların birbirleri ile olan etkileşimlerini önlemek amacıyla ölçek uygulamaları sınıf ortamı dışında yapılmıştır. Ölçeğin uygulama süresi 15 ile 25 dakika arasında değişmektedir. İkinci ve üçüncü oturumlarda Frederick ve Ağustos Böceği ile Karınca hikâyeleri çocuklara okunmuştur. Sıra etkisini önlemek amacıyla çocuklara kitaplar tesadüfi sıra ile okunmuştur. Hikâye okuma sonrası çocuklara hikâye anlama soruları bireysel olarak sorulmuştur. Çocukların cevapları ses kaydına alınmıştır. Çocukların hikâye anlama sorularını cevap süreleri 10 ile 20 dakika arasında değişmektedir. Tablo 1'de araştırmanın uygulama süreci detaylı olarak sunulmaktadır.

Tablo 1. Araştırmanın Uygulama Süreci

\begin{tabular}{lccc}
\hline & $1 . \quad$ Oturum & 2. Oturum & 3. Oturum \\
\hline Ön değerlendirme & $\begin{array}{c}\text { Zihin Kuramı Ölçeği } \\
\left(n_{\text {cocuk }}=133\right)\end{array}$ & & \\
Uygulama & & Hikâyenin okunması & Hikâyenin okunması \\
& & Frederick & Ağustos Böceği ile Karınca \\
& & Ağustos Böceği ile Karınca & Frederick
\end{tabular}

Son Değerlendirme

Hikâye Anlama Soruları

Hikâye Anlama Soruları

\section{Verilerin Analizi}

Çocukların hikâye anlama sorularına verdikleri cevaplar transkript edilip araştırmacılar tarafından bağımsız puanlanmıştır. Kodlayıcılar arası tutarlığı test etmek için Pearson Momentler Çarpımı Korelasyon katsayısı hesaplanmışır. Korelasyon güvenirlilik katsayısı Frederick için .92 ve Ağustos Böceği ve Karınca için 96 olarak bulunmuştur. Zihin Kuramı puanları ve hikâye anlama puanları SPSS paket programına aktarılarak analizler yapılmıştır.

\section{Bulgular}

Bu bölümde öncelikle Zihin Kuramı ve hikâye anlama puanlarına ilişkin betimsel analiz sonuçları sunulmuştur. Daha sonra çalışmada toplanan veriler, bağımsız gruplar t-testi ve Pearson 
Korelasyon testleri ile analiz edilmiştir. Elde edilen bulgular tablolar halinde sunulmuştur. Araştırmanın analizlerine başlamadan önce ilk olarak, Zihin Kuramı ve hikâye anlama puanlarının normal dağılım durumlarına ilişkin çarpıklık-basıklık (skewness-kurtosis) değerlerine bakılmış ve değerlerin $+2,-2$ aralığında olduğu belirlenmiştir. Bu değer aralığıyla puanların normal dağılım gösterdiği kabul edilmiş ve belirtilen analizler yürütülmüştür (Field, 2009). Tablo 2'de Zihin Kuramı ve hikâye anlama puanlarına ilişkin betimsel istatistik sonuçları sunulmaktadır.

Tablo 2. Zihin Kuramı ve Hikâye Anlama Puanlarına Ilişkin Betimsel Istatistikler

\begin{tabular}{llllll}
\hline & $n$ & Min & Max & $\bar{X}$ & SS \\
\hline Zihin Kuramı & 133 & 0 & 5.00 & 3.08 & 1.24 \\
Hikâye Anlama & 133 & 0 & 20 & 9.68 & 3.02
\end{tabular}

Tablo 2'de görüldüğü üzere, okul öncesi dönem çocuklarının Zihin Kuramı Ölçeği'nden aldıkları puanlar 0 ile 5 arasında değişmektedir. Araştırma kapsamına alınan çocukların Zihin Kuramı puan ortalamasının 3.08 (SS = 1.24) olduğu görülmektedir. Çocukların iki hikâyeden aldıkları toplam hikâye anlama puanları 0 ile 20 puan arasında değişmektedir. Tablo 2 incelendiğinde, çocukların hikâye anlama puan ortalamasının 9.68 (SS = 3.02) olduğu görülmektedir.

\section{Zihin Kuramı Ölçeği'ne ilişskin Bulgular}

Çocukların, Zihin Kuramı Ölçeği alt maddelerine göre doğru cevap dağılımları Şekil 1'de sunulmuştur. Çocuklarının Zihin Kuramı Ölçeği'nden aldıkları puanların cinsiyete göre dağılımları incelendiğinde Farklı İstek görevi hem kız (\%90) hem erkek (\%78) çocuklar tarafından en çok doğru yapılan görev iken, İçerik Yanlış Inanç görevi çocuklar (kız: \%30, erkek= \%18) tarafından en az doğru yapılan görev olduğu tespit edilmiştir.

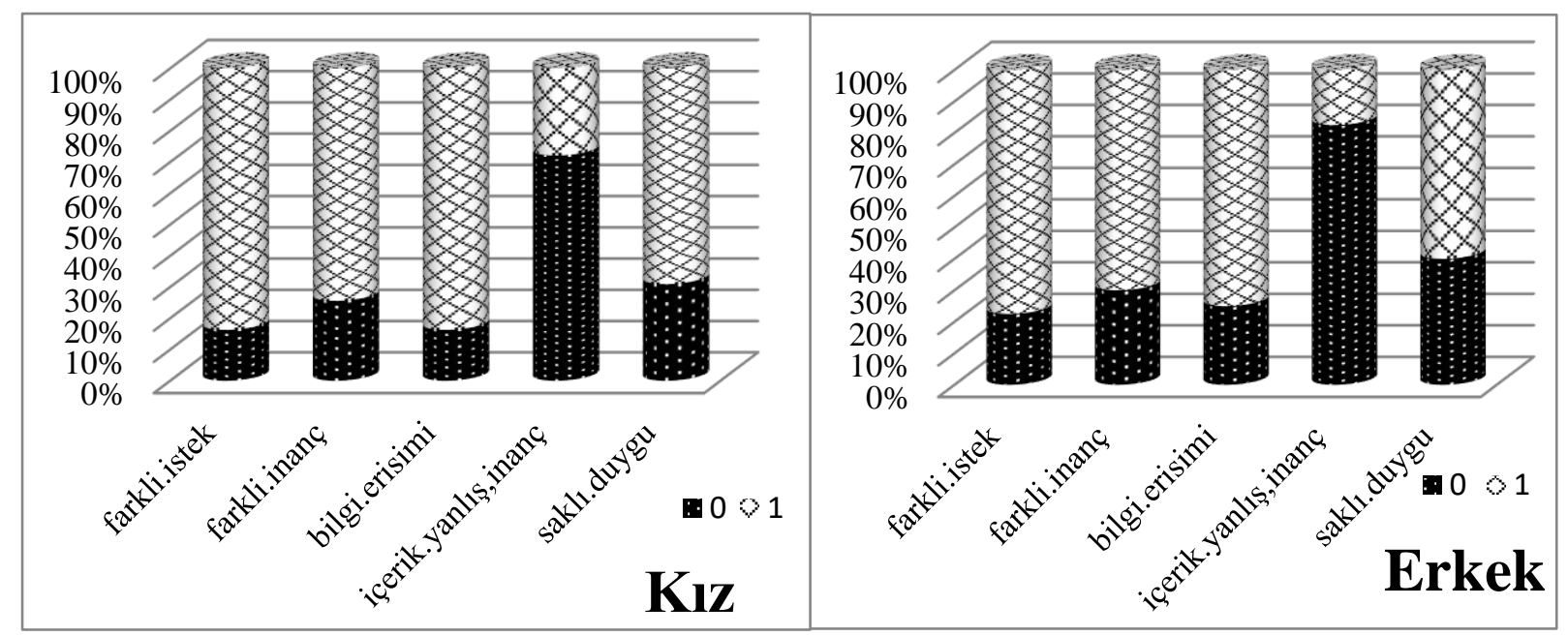

Şekil 1. Çocuklarının Zihin Kuramı Ölçeğinden Aldıkları Puanların Cinsiyete Göre Dağılımları 
Okul öncesi dönem çocuklarının Zihin Kuramı puanlarının cinsiyete göre farklılaşıp farklılaşmadığını tespit etmek için bağımsız gruplar t-testi yapılmıştır. Tablo 3 incelendiğinde, araştırma kapsamına alınan çocukların Zihin Kuramı puanları arasında cinsiyet değişkeni açısından kızlar lehine anlamlı bir fark bulunmuştur $(\mathrm{t}(131)=2.279, \mathrm{p}<.05) . \mathrm{K} ı \mathrm{z}(\bar{X}=3.14, \mathrm{SS}=1.11)$ ve erkek $(\bar{X}=3.01, \quad$ SS $=1.37)$ çocukların puanları arasında bulunan anlamlı farkın etki değeri ( $\eta 2)$ hesaplanmıştır. Hesaplanan eta kare değeri incelendiğinde ( $12=.03)$ gruplar arasında bulunan farka ilişkin etki değerinin küçük olduğu görülmektedir.

Tablo 3. Okul Öncesi Dönem Çocuklarının Zihin Kuramı Puanlarının Cinsiyet Değişkenine Göre Bağımsız Gruplar t-Testi Sonuçları

\begin{tabular}{lllllll}
\hline Zihin Kuramı & $n$ & $\bar{X}$ & SS & $t$ & $p$ & $\eta^{2}$ \\
\hline Kız & 67 & 3.14 & 1.11 & 2.279 & .024 & .03 \\
Erkek & 66 & 3.01 & 1.37 & & & \\
\hline
\end{tabular}

Hikâye Anlama Sorularına ilişkin Bulgular

Hikâye anlama sorularından alınan puanların cinsiyete göre dağılımları incelendiğinde, kız ve erkek çocukların en çok hikâyede geçen karakterlere yönelik sorulara doğru cevap verdikleri tespit edilmiştir. Şekil 2 incelendiğinde, çocukların en az puanı çözüm-sonuç sorularından aldıkları görülmektedir.

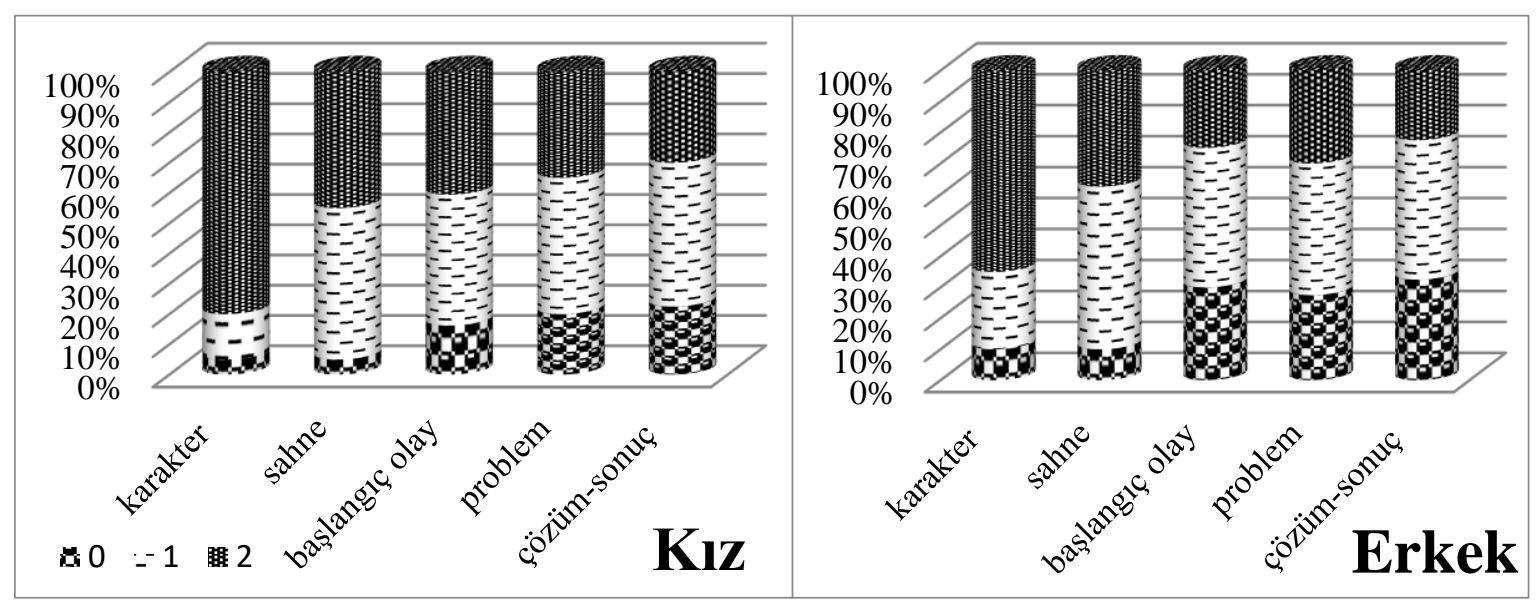

Şekil 2. Hikâye Anlama Sorularından Alınan Puanların Cinsiyete Göre Dağılımları

Çocukların hikâye anlama sorularından aldıkları puanlarının cinsiyete göre farklılaşıp farklılaşmadığını tespit etmek için bağımsız gruplar t-testi yapılmıştır. Tablo 4 incelendiğinde; araştırma kapsamına alınan çocukların hikâye anlama puanları arasında cinsiyet değişkeni açısından kızlar lehine anlamlı bir fark bulunmuştur $(\mathrm{t}(131)=2.946, \mathrm{p}<.05) . \mathrm{K} ı \mathrm{z}(\bar{X}=10.43, \mathrm{SS}=2.40)$ ve erkek ( $\bar{X}=8.93, \mathrm{SS}=3.39$ ) çocukların puanları arasında bulunan anlamlı farkın etki değeri ( $\eta 2)$ 
hesaplanmıştır. Hesaplanan eta kare değeri incelendiğinde ( $\eta 2=.06)$ gruplar arasında bulunan farka ilişkin etki değerinin orta düzeyde olduğu görülmektedir.

Tablo 4. Hikâye Anlama Puanlarının Cinsiyet Değişkenine Göre Bağımsız Gruplar t-Testi Sonuçları

\begin{tabular}{|c|c|c|c|c|c|c|}
\hline Hikâye Anlama & $n$ & $\bar{X}$ & SS & $t$ & $p$ & $\eta^{2}$ \\
\hline Kız & 67 & 10.43 & 2.40 & 2.946 & .004 & .06 \\
\hline Erkek & 66 & 8.93 & 3.39 & & & \\
\hline
\end{tabular}

Zihin Kuramı ile Hikâye Anlama Puanları Arasındaki ilişkinin Incelenmesi

Zihin Kuramı ile Hikâye Anlama Puanları arasındaki ilişkiyi incelemek amacıyla Pearson Korelasyon testi uygulanmıştır. Analiz öncesinde veri setinde uç değer olup olmadığı dağılım grafikleri (scatterplot) kontrol edilmiş ve uç değer bulunmadığı gözlenmiştir. Tablo 5'te Zihin Kuramı ile hikâye anlama puanları arasındaki Korelasyon analizi sonuçlarını sunulmuştur.

Tablo 5. Zihin Kuramı ile Hikâye Anlama Puanları Arasındaki Korelasyon Analizi Sonuçları

\begin{tabular}{lll}
\hline & & Hikâye Anlama Toplam Puan \\
\hline 1. & Farklı İstek & $.168^{*}$ \\
2. & Farklı İnanış & $.219^{*}$ \\
3. & Bilgi Erişimi & $.242^{*}$ \\
4. & İçerik yanlış inanç & $.431^{* *}$ \\
5. & Saklı Duygular & $.361^{* *}$ \\
6. & Zihin Kuramı Toplam Puan & $.468^{* *}$ \\
\hline$* \mathrm{p}<.05 * * \mathrm{p}<.01$ &
\end{tabular}

Tablo 5'te görüldüğü üzere, Pearson Korelasyon analiz sonuçlarına göre hikâye anlama toplam puanları ile Zihin Kuramı ölçek toplam puanları arasında pozitif yönlü orta düzeyde bir ilişki bulunmaktadır ( $r=.46, p<.01)$. Tablo 5 incelendiğinde, Zihin Kuramı ölçeği alt görevleri ile hikâye anlama toplam puan arasında en yüksek ilişkinin İçerik Yanlış inanç görevi $(r=.43, p<.01)$ ile en düşük ilişkinin Farklı istek görevi ( $r=.16, p<.01)$ ile olduğu görülmektedir.

\section{Tartışma, Sonuç ve Öneriler}

Bu çalışmada okul öncesi dönem çocuklarının Zihin Kuramı ile hikâye anlama becerileri arasındaki ilişkinin incelenmesi hedeflenmiştir. Ayrıca, çalışma kapsamında çocukların cinsiyet değişkenine göre hikâye anlama ve Zihin Kuramı puanlarında farklılaşma olup olmadığı araştırılmıştır. Araştırma sonucunda, Zihin Kuramı puanları arasında cinsiyet değişkeni açısından kızlar lehine anlamlı bir fark bulunmaktadır. Okul öncesi dönem Zihin Kuramı gelişiminde bireysel farklılıkları inceleyen araştırmaların çoğunun cinsiyet konusunu ele almadığı görülmektedir. Bunun bir sebebi, Zihin Kuramı'na göre cinsiyete yönelik farkın yaş ilerledikçe ortaya çıktığı düşüncesinin hâkim olması 
Okul Öncesi Dönem Çocuklarının Hikâye Anlama ile Zihin Kuramı Becerileri Arasındaki ilişskinin İncelenmesi

olabilir (Calero, Salles, Semelman ve Sigman, 2013). Cinsiyet değişkenini ele alan araştırmalar arasında cinsiyet değişkeni açısından fark bulamayan araştırmalar da alan yazında mevcuttur (Pelletier ve Beatty, 2015; Walker, 2005). Bununla birlikte, okul öncesi dönemdeki Zihin Kuramı'na ilişkin saklı duyguyu anlamaları ve yanlış inanış yönergesi performansına ilişkin kızların az bir farkla da olsa daha yüksek performans gösterdikleri gözlemlenmiştir (Banerjee, 1997; Calero vd., 2013; Charman, Ruffman ve Clements, 2002). Calero vd., (2013) tarafından 6-8 yaş arası çocuklarda Zihin Kuramı́nın yaş ve cinsiyete bağlı gelişiminin incelendiği araştırmada kızların tüm Zihin Kuramı yönergelerinde erkeklerden çok daha iyi performans gösterdiği bulunmuştur.

Çocukların ebeveynleriyle kurduğu iletişimin ve diyalogların içeriği zihinsel durumlarını anlama becerilerini etkilediği görülmektedir. Üç-dört yaş çocukların anneleriyle kurdukları iletişimde zihinsel durumlara ilişkin dil kullanım sıklığının çocukların yanlış inanış yönergesine verdikleri cevapla pozitif yönde ilişkilidir (Adrian vd., 2005; Ruffman, Slade \& Crowe, 2002). Ruffman, Slade ve Crowe (2002) anne-çocuk kitap okuma sürecindeki konuşmalardaki zihinsel durum ögelerini ve ögelerin Zihin Kuramı ile arasındaki ilişkiyi araştırmışlardır. Anne ve çocuğun konuşmalarında annenin kullandığı zihinsel duruma ilişkin kelimelerin sıklığının çocukların Zihin Kuramı becerileri üzerinde pozitif etki yarattığı görülmektedir. Ayrıca bu durumun daha ileri düzeydeki Zihin Kuramı becerileriyle ilişkili olduğunu ortaya koymuşlardır. Bu durumun açıklaması olarak, ebeveynler (özellikle anneler) ve çocuklar arasında gerçekleşen diyalogların sıklığı ve içeriği bireysel farklılıklara neden olabilmektedir. Annelerin bebeklik döneminden itibaren kız çocuklarıyla erkek çocuklarından daha fazla konuştuğu tespit edilmiştir (Leaper, Anderson ve Saunders, 1998). Ayrıca, annelerin iki yaşından sonra kız çocuklarıyla duygulara yönelik olarak daha çok konuştuğu ve bunun da çocuğun ileride duygu içerikli konuşma durumuna olumlu yönde katkı sağladığı düşünülmektedir (Fivush, Brotman, Buckner ve Goodman, 2000).

Araştırmaya katılan hem kız hem de erkek çocukların büyük çoğunluğunun hikâyeye ilişkin karakter ve sahneye yönelik sorulara doğru cevap verdikleri görülmüştür. Yapılan çalışmalar benzer şekilde çocukların karakter ve sahne gibi hikâye yapısıyla ilgili yüzeysel bilgi içeren sorulara daha yüksek oranda doğru cevap verdiklerini göstermektedir (Altun, 2018; Paris ve Paris, 2003). Bununla birlikte, çocukların toplam hikâye anlama puanları arasında cinsiyet değişkeni açısından kızlar lehine anlamlı bir fark bulunmuştur. Araştırma bulguları, kızların yapı ve karmaşıklık açısından erkeklere göre daha detaylı hikâyeler anlattığını ortaya koyan araştırma sonuçlarıyla tutarlılık göstermektedir (Gardner-Neblett ve Sideris, 2017; Fey, Catts, Proctor-Williams, Tomblin ve Zhang, 2004; Lynch, van den Broek, Kremer, Kendeou, White ve Lorch, 2008). Gardner-Neblett ve Sideris (2017) tarafından yürütülen araştırmanın sonucu Afro-Amerikan erkek ve kızların, okula başlamadan önce hikâye anlatma becerilerinin farklılaştığını göstermektedir. Bu araştırmada yapılan analizlerin sonucunda, 
okul öncesi dönemde kızların hikâye anlatımlarının erkeklerin hikâye anlatımlarına kıyasla daha tutarlı ve düzenli olduğu ortaya konmuştur. Kız çocuklarının, hikâye anlatımlarını hikâye ögelerine ve bu ögeler arasındaki nedensel ilişkiler çerçevesinde yapılandırdığı görülmektedir. Lynch vd. (2008) tarafından yürütülen araştırma bulguları ise, okul öncesi dönem çocuklarının uzun ve karmaşık hikâyelerde olaylar arasındaki nedensel ilişkilere karşı duyarlı olduklarını göstermektedir. Çocukların yaşı ilerledikçe daha fazla soruya doğru cevap verdiği, aynı zamanda anlatıların nedensel yapısına daha duyarlı olduğu bulunmuştur. Ayrıca kızların her yaş grubunda erkeklerden daha fazla hikâyeyi hatırladıkları görülmüştür.

Araştırma sonuçlarına göre hikâye anlama puanları ile Zihin Kuramı Ölçek puanları arasında pozitif yönlü orta düzeyde bir ilişki bulunmaktadır. Araştırmanın bu sonucu Zihin Kuramı ve hikâye anlatımı arasında pozitif yönlü ilişki bulan araştırma sonuçlarını desteklemektedir (Gamannossi ve Pinto, 2014; Guajardo ve Watson, 2002; Mar, Tackett ve Moore, 2010; Sarı, 2018). Gamannossi ve Pinto (2014) tarafından yürütülen araştırmada çocukların hikâye anlatımında kullandıkları zihinsel durumları ifade eden dil becerisi ile çocukların zihinsel durumları anlama düzeyleri incelenmiştir. Araştırma sonucunda, hikâye anlama becerisi ile hikâye anlatımında zihinsel durumları ifade eden dil arasında güçlü bir ilişki $(r=.79)$ olduğu tespit edilmiştir. Bununla birlikte, Sarı (2018) okul öncesi dönem çocuklarının hikâye tekrarda kullandıkları içerik kelime düzeyi $(r=.31)$ ve hikâyedeki örtük olayları anlama becerisi ( $r=.25$ ) ile Zihin Kuramı puanları arasındaki pozitif yönlü düşük düzeyde bir ilişki bulmuştur. Zihin Kuramı ve hikâye anlama arasındaki pozitif ilişkinin derecesi araştırmalara göre değişse de Zihin Kuramı becerisinin çocukların hikâye anlama becerisine katkıda bulunduğu görülmektir (Mar vd., 2010; Guajardo ve Watson, 2002). Mar vd. (2010) tarafından yürütülen bir araştırmada farklı türde hikâye anlatımı biçimlerinin çocukların Zihin Kuramı gelişimine etkisi araştırımıştır. Araştırmada hikâye kitabı okumanın, film ve televizyon izlemenin çocukların Zihin Kuramı becerilerine etkisi ayrı olarak test edilmiştir. Araştırma sonucunda yaş, cinsiyet, kelime bilgisi ve ailelerin sosyo-ekonomik düzeyleri kontrol edildiğinde çocuklara hikâye kitabı okumanın çocukların zihinsel becerilerini yordadığı görülmüştür. Guajardo ve Watson (2002) hikâye anlatma sürecinde kullanılan zihinsel duruma ilişkin kavramların kullanımının Zihin Kuramı becerilerini geliştirip geliştirmediğini araştırmışlardır. Araştırma sonucunda kurum temelli hikâye anlatma grubunda yer alan çocukların yanlış inanış yönergesinde daha iyi performans gösterdiklerini bulmuşlardır. Ayrıca, sohbete katılan çocuklar katılmayan çocuklara göre Zihin Kuramı becerilerinde daha yüksek performans göstermişlerdir.

Okul öncesi öğretmenlerinin ve anne-babaların hikâye anlatımı sürecinde, hikâyede yer alan karakterlerin duygu durumlarına ilişkin dil kullanımı ve sohbet esnasında çocukları bu dili kullanması için yönlendirmesi önemlidir. Çocuklar bu sayede zamanla faklı bakış açılarıyla düşünebilme ve 
muhakeme yapabilme becerilerini geliştirebilmektedirler. Illeride yapılacak olan çalışmalarda okul öncesi dönem çocuklarıyla yürütülecek etkileşimli hikâye okuma etkinliklerinin çocukların Zihin Kuramı becerileri üzerindeki etkileri incelenerek bu alanda yapılan araştırmalar genişletilebilir.

\section{Kaynaklar}

Adrian, J. E., Clemente, R. A., Villanueva, L., \& Rieffe, C. (2005). Parent-child picture-book reading, mothers' mental state language and children's theory of mind. Journal of Child Language, 32(3), 673-686.

Altun, D. (2018). The efficacy of multimedia stories in preschoolers' explicit and implicit story comprehension. Early Childhood Education Journal, 46(6), 629-642. doi:10.1007/s10643-018-0916-8

Astington, J. W. (1990). Narrative and the child's theory of mind. In B. Britton \& A. Pellegrini (Eds.), Narrative thought and narrative language (ss. 151-171). Hillsdale, NJ: Erlbaum.

Astington, J. W., \& Jenkins, J. M. (1999). A longitudinal study of the relation between language and theory of mind development. Developmental Psychology, 35, 1311-1320.

Atkinson, L., Slade, L., Powell, D., \& Levy, J. P. (2017). Theory of mind in emerging reading comprehension: A longitudinal study of early indirect and direct effects. Journal of Experimental Child Psychology, 164, 225-238.

Banerjee, M. (1997). Hidden emotions: Preschoolers' knowledge of appearance-reality and emotion display rules. Social Cognition, 15(2), 107-132. doi:10.1521/soco.1997.15.2.107

Başal, H. A. (2012). Gelişim ve psikoloji: Nasıl mutlu ve başarılı bir çocuk yetiştirebilirim? Bursa: Ekin Basım Yayın Dağıtım.

Calero, C. I., Salles, A., Semelman, M., \& Sigman, M. (2013). Age and gender dependent development of Theory of Mind in 6- to 8-years old children. Frontiers in Human Neuroscience, 7, 281. doi:10.3389/fnhum.2013.00281

Charman, T., \& Shmueli-Goetz, Y. (1998). The relationship between theory of mind, language and narrative discourse: an experimental study. Current Psychology of Cognition, 17(2), 245-271.

Charman, T., Baron-Cohen, S., Swettenham, J., Baird, G., Cox, A., \& Drew, A. (2000). Testing joint attention, imitation, and play as infancy precursors to language and theory of mind. Cognitive Development, 15(4), 481-498.

Charman, T., Ruffman, T., \& Clements, W. (2002). Is there a gender difference in false belief development?. Social Development, 11(1), 1-10.

Demir-Lira, Ö. E. (2016). Okulöncesi dönemde ve okul çağında okuma yazma ve matematik gelişimi. Aklın çocuk hali: Zihin gelişimi araştırmaları (Der. Aydın, Ç., Aydin, C., Göksun, T., Goksun, T., Kuntay, A. C., Tahiroğlu, D., \& Tahiroglu, D.). ( ss. 319-342). İstanbul: Koç Üniversitesi Yayınları.

Duff, F. J., Reen, G., Plunkett, K., \& Nation, K. (2015). Do infant vocabulary skills predict school-age language and literacy outcomes?. Journal of Child Psychology and Psychiatry, 56(8), 848-856.

Duncan, G. J., Dowsett, C. J., Claessens, A., Magnuson, K., Huston, A. C., Klebanov, P., ... \& Sexton, H. (2007). School readiness and later achievement. Developmental Psychology, 43(6), 1428. doi: 10.1037/00121649.43.6.1428

Dyer, J. R., Shatz, M., \& Wellman, H. M. (2000). Young children's storybooks as a source of mental state information. Cognitive Development, 15 (1), 17-37 doi:10.1016/S0885-2014(00)00017-4

Fernández, C. (2013). Mindful storytellers: Emerging pragmatics and theory of mind development. First Language, 33(1), 20-46. doi: 10.1177/0142723711422633 
Fey, M. E., Catts, H. W., Proctor-Williams, K., Tomblin, J. B., \& Zhang, X. (2004). Oral and written story composition skills of children with language impairment. Journal of Speech, Language, and Hearing Research, 47(6), 1301-1318.

Field, A. (2009). Discovering statistics using SPSS. London: SAGE.

Fivush, R., Brotman, M. A., Buckner, J. P., \& Goodman, S. H. (2000). Gender differences in parent-child emotion narratives. Sex Roles, 42(3-4), 233-253.

Flavell, J. H. (2000). Development of children's knowledge about the mental world. International Journal of Behavioral Development, 24(1), 15-23. doi: 10.1080/016502500383421

Fraenkel, J. R., Wallen, N. E., \& Hyun, H. H. (2012). How to design and evaluate research in education. New York: McGraw-Hill.

Gamannossi, B. A., \& Pinto, G. (2014). Theory of mind and language of mind in narratives: Developmental trends from kindergarten to primary school. First Language, 34(3), 262-272.

Gardner-Neblett, N., \& Sideris, J. (2017). Different tales: The role of gender in the oral narrative-reading link among African American children. Child Development, 89(4), 1328-1342. doi: 10.1111/cdev.12803.

Gözün- Kahraman, Ö. (2012). Zihin kuramına dayalı eğitim programının 48-60 aylık çocukların bilişsel bakış açısı becerileri ve prososyal davranışları üzerindeki etkisinin incelenmesi. Yayımlanmamış Doktora Tezi. Gazi Üniversitesi, Eğitim Bilimleri Enstitüsü, Ankara.

Grazzani, I., Ornaghi, V., Conte, E., Pepe, A., \& Caprin, C. (2018). The Relation between Emotion Understanding and Theory of Mind in Children Aged 3 to 8: The Key Role of Language. Frontiers in Psychology, 9:724. doi: 10.3389/fpsyg.2018.00724

Guajardo, N. R., \& Watson, A. C. (2002). Narrative discourse and theory of mind development. The Journal of Genetic Psychology, 163(3), 305-325.

Karaağaç, G. (2010). Türkçenin ses bilgisi. İstanbul: Bayrak Matbaacılık.

Keçeli-Kaysılı, B., \& Acarlar, F. (2011). Zihin Kuramının 3-5 yaşları arasındaki çocuklarda gelişiminin yanlış inanç performansına göre incelenmesi. Kuram ve Uygulamada Eğitim Bilimleri, 11(4), 1809-1826.

Leaper, C., Anderson, K. J., \& Sanders, P. (1998). Moderators of gender effects on parents' talk to their children: a meta-analysis. Developmental Psychology, 34(1), 3.

Lynch, J. S., van Den Broek, P., Kremer, K. E., Kendeou, P., White, M. J., \& Lorch, E. P. (2008). The development of narrative comprehension and its relation to other early reading skills. Reading Psychology, 29(4), 327-365.

Mar, R. A., Tackett, J. L., \& Moore, C. (2010). Exposure to media and theory-of-mind development in preschoolers. Cognitive Development, 25(1), 69-78.

Milligan, K., Astington, J. W., \& Dack, L. A. (2007). Language and Theory of Mind: meta-analysis of the relation between language ability and false-belief understanding. Child Development, 78(2), 622-646. doi: 10.1111/j.1467-8624.2007.01018.x

Minai, U., Gustafson, K., Fiorentino, R., Jongman, A., \& Sereno, J. (2017). Fetal rhythm-based language discrimination: A biomagnetometry study. NeuroReport, 28 (10), 561-564. doi: 10.1097/WNR.0000000000000794

Morrow, L. M. (1985). Retelling stories: A strategy for improving young children's comprehension, concept of story structure, and oral language complexity. The Elementary School Journal, 85, 646-661

Paris, A. H., \& Paris, S. G. (2003). Assessing narrative comprehension in young children. Reading Research Quarterly, 38(1), 36-76. 
Pelletier, J., \& Astington, J. W. (2004). Action, consciousness and Theory of Mind: Children's ability to coordinate story characters' actions and thoughts. Early Education and Development, 15(1), 5-22 doi:10.1207/s15566935eed1501_1

Pelletier, J., \& Beatty, R. (2015). Children's understanding of Aesop's fables: relations to reading comprehension and theory of mind. Frontiers in Psychology, 6, 1448.

Peskin, J., \& Astington, J. W. (2004). The effects of adding metacognitive language to story texts. Cognitive Development, 19(2), 253-273.

Ruffman, T., Slade, L., \& Crowe, E. (2002). The relation between children's and mothers' mental state language and theory-of-mind understanding. Child Development, 73(3), 734-751.

Ruffman, T., Slade, L., Rowlandson, K., Rumsey, C., \& Garnham, A. (2003). How language relates to belief, desire, and emotion understanding. Cognitive Development, 18(2), 139-158 doi:10.1016/S08852014(03)00002-9

Sakai, K. L. (2005). Language acquisition and brain development. Science, 310(5749), 815-819.

Sarı, B. (2018). Elektronik Hikâye Kitaplarının Farklı Sosyo-Ekonomik Düzeyden Gelen 4-6 Yaş Çocukların Anlamlı Kelime Edinimleri Üzerine Etkisi. Yayımlanmamış Doktora Tezi, Bursa: Uludağ Üniversitesi, Eğitim Bilimleri Enstitüsü.

Sipe, L. R. (2008). Storytime: Young children's literary understanding in the classroom. New York: Teachers College Press.

Stein, N. L. (1978). How children understand stories: A developmental analysis. Center for the Study of Reading Technical Report. 22 Ocak 2017 tarihinde https:/www.ideals.illinois.edu/ bitstream/ handle/ 2142/17672/ctrstreadtechrepv01978i00069_opt.pdf?sequence adresinden alınmıştır.

Su, M., Peyre, H., Song, S., McBride, C., Tardif, T., Li, H., ... \& Shu, H. (2017). The influence of early linguistic skills and family factors on literacy acquisition in Chinese children: Follow-up from age 3 to age 11. Learning and Instruction, 49, 54-63.

Suggate, S., Schaughency, E., McAnally, H., \& Reese, E. (2018). From infancy to adolescence: The longitudinal links between vocabulary, early literacy skills, oral narrative, and reading comprehension. Cognitive Development, 47, 82-95.

Sulzby, E. (1985). Children's emergent reading of favorite storybooks: A developmental study. Reading Research Quarterly, 458-481.

Walker, S. (2005). Gender differences in the relationship between young children's peer-related social competence and individual differences in theory of mind. The Journal of genetic psychology, 166(3), 297-312.

Wellman, H. M. (2014). Making minds: How Theory of Mind develops. Oxford: Oxford University Press.

Wellman, H. M., \& Liu, D. (2004). Scaling of Theory-of-Mind tasks. Child Development, 75(2), 523-541 doi: 10.1111/j.1467-8624.2004.00691.x

Yılmaz, Z. A. (2009). Uygulama örnekleriyle ilk okuma-yazma öğretimi. Ankara: Nobel Yayın Dağıtım.

\section{Araştırma Kapsamında Kullanılan Resimli Çocuk Kitapları}

Lionni, L. (2016). Frederick. Ankara: Elma Yayınları.

Sims, L. (2016). Ağustos böceği ile karınca. Ankara: 1001 Çiçek Kitaplar.

\section{Extended Abstract \\ Introduction}

Talking with children about mental states of the storybook characters during the storybook reading activities improve children's reasoning skills and help them to think from the point of view of the main character/author/reader (Pelletier \& Astington, 2004). It is observed that the Theory of Mind skills of young 
children are associated with their general language skills (Adrian et al., 2005; Ruffman, Slade, \& Crowe, 2002) and story comprehension skills (Gamannossi \& Pinto, 2014; Pelletier \& Beaty, 2015). Pelletier and Beaty (2015) conducted a correlational study between children's abilities to understand Aesop's Fables and the Theory of Mind and found a positive correlation between the story comprehension levels of preschool children and the Theory of Mind skills. Based on this fact, this study aims to reveal the relationship between the Theory of Mind and story comprehension skills of Turkish preschool children at the ages of 5-6.

Method

This study examines the correlation between the Theory of Mind and story comprehension skills of Turkish preschoolers. The study group consists of 133 (67 girls and 66 boys) children studying at four public kindergartens that are located in the central district of Kırşehir, Turkey in the Fall semester of the 2017-2018 academic year. The study group was formed through convenience sampling, which is a non-random sampling method (Fraenkel, Wallen, \& Hyun, 2012). After the necessary ethical and application permissions were obtained for the study, information and parent permission forms were sent to parents.

The study data were collected, using the Theory of Mind Scale and Story Comprehension Questions. Two stories, titled Frederick and Ağustos Böceği ile Karınca [The Ant and the Grasshopper] were read to the children during the study.

The study data were collected in three sessions, taking into account the attention span of the preschool children. The Theory of Mind Scale was applied to the children one by one in the first session. The scale was applied outside the classroom in order to prevent the children from interacting with each other. Frederick and Ağustos Böceği ile Karınca [The Ant and the Grasshopper] stories were read to the children in the second and third sessions. The books were read randomly to the children in order to prevent the order effect. The story comprehension questions were asked to the children individually after the story reading activity.

\section{Result \& Discussion}

An independent samples t-test was conducted to determine whether the Theory of Mind scores of the preschool children differed by gender. A significant difference in favor of the girls was found in the Theory of Mind scores in terms of gender $(t(131)=2.279, p<.05)$. The effect value $(n 2)$ of the significant difference found between the girls $(\underline{X}=3.14, \mathrm{SD}=1.11)$ and boys $(\underline{X}=3.01, \mathrm{SD}=1.37)$ was calculated.

An independent samples t-test was conducted to determine whether the scores obtained by the children from the story comprehension questions differed by gender. A significant difference in favor of the girls was found between the story comprehension scores of the children included in the study in terms of gender $(t(131)=2.946, p<.05)$. The effect value $(n 2)$ of the significant difference found between the girls $(\underline{X}=10.43, \mathrm{SD}=2.40)$ and boys $(\underline{X}=8.93, \mathrm{SD}=3.39)$ was calculated.

Pearson's correlation test was conducted in order to examine the relationship between the Theory of Mind and the story comprehension scores. According to the results of the correlation analysis, there is a moderate positive correlation between the story comprehension and Theory of Mind $(r=46, p<.01)$. The highest correlation between the subtasks of the Theory of Mind Scale and story comprehension was in the contents false belief task $(r=43, p<.01)$, while the lowest correlation was in the Diverse Desires task $(r=16$, $\mathrm{p}<.01)$. This result of the study supports the results of studies showing a positive correlation between the Theory of Mind and story comprehension (Gamannossi \& Pinto, 2014; Guajardo \& Watson, 2002; Mar, Tackett \& Moore, 2010; Sari, 2018). 